\title{
THE INVESTIGATION OF LIMITING FACTORS OF EARNINGS MANAGEMENT FOR COMPANIES' LISTED TEHRAN STOCK EXCHANGE
}

\author{
E. Tangestani ${ }^{1, *}$, V. Asgari ${ }^{1}$ and, I. Jahed ${ }^{2}$ \\ ${ }^{1}$ M.A of University Nour ,iran \\ ${ }^{2}$ M.A of University zahedan,iran
}

Published online: 16 July 2016

\begin{abstract}
The current study was to examine the limiting factors of earnings management for companies' listed Tehran stock exchange. The study was a kind of applied, descriptive-correlative research. All listed companies in Tehran stock exchange were selected as statistical population during 2009 to 2013 . So, data was gathered by library method and collected by systematic eliminated sampling method. The results show that there is a significant inverse relationship between board size and earnings management in companies' listed Tehran stock exchange. The result doesn't show any significant relationship between dividend and earnings management in companies' listed Tehran stock exchange.
\end{abstract}

Keywords: real earnings management; accrual earnings management; discretionary accruals; non-discretionary accruals; intensive factors

Author Correspondence, e-mail: Ehsan.tangestani85@yahoo.com doi: http://dx.doi.org/10.4314/jfas.v8i2s.93

\section{INTRODUCTION}

There are two main motives for earnings manipulation (earnings management). One of them is investment encouraging for buying firms' stock and the other one is increasing in firms' market value (Klag, 1991). One of the ways for earning manipulation is using accruals. 
Because, accrual accounting system offers right to managers in order to choose earnings determinant in different times. In accrual accounting system, managers face different options about the time of revenue and expenses recognition. For example credit sale is early recognition of revenue (Teoh et al, 1998). This kind of manager performance is called earnings management. Manager earnings manipulation decreases earning quality. Managers adjust reported earnings by choosing specific accounting policies, accounting estimates and accrual management.

Hant, Moier and Shelvin (1997) suggest that lower reported earnings increase capital market value. Obviously, integration in financial statement is affected by manager personal opinion for decreasing earnings number. Earnings management has negative impact at the time of detection. By earnings management accounting, manager can change others' imagination about firm performance. When some errors are detected the firm cannot be reliable, so the debt and capital price will be decreased (Sahar Sepasi, 2005).

\section{Theoretical framework}

Manager intervention in accounting information has been named variously. The common term of this issue in accounting and financial literature is earnings management. Shiper (1989) describes earnings management as manager intervention in external financial reporting process in order to reach personal earnings. Earnings management phenomenon is rooted in manager opportunistic behavior. In fact, earnings management is a kind of managerial performance that retrieved from accounting and agency theories, so leads to information asymmetry between managers and other users (investors). In the other hand, earnings management can be investigated in efficient market theories. Hence, managers are motivated to earnings manipulation (Wats \& Zimmerman, 1986). Nowadays, earnings management determinants and information discloser in capital market has been interesting (Fernandez \& Garcia, 2007). In fact, the reason for earnings management is so important for policymakers, analysts, specialists and finance executives (Banish, 1999; Kuthary et al, 2005).

Kapland described the ability of decreasing or increasing in reported earnings by managers as account manipulation. Account manipulation has wider concept. For example, the way of items categories in income statement is so considered in accounting literature. The importance of account manipulation is more than Kapland description. Manipulation incentive needs more attention. Managers sometimes use accounts as an instrument for showing unreal firms target or artificial risk reduction. 
Estimates of the power and actions of managers are the one of the fundamental factors for earnings management test. The investigation of literature based on earnings management show the existence of different approaches in estimation of managers' power to earnings determination. One of the most important approaches is based on discretionary accruals. Healy, DeAnjelo and Jones examined earnings management and the use of accruals for earnings management detection. So they suggest some models for future research. Dechow et al show that Jones adjusted model detect earnings management in a better way.

Jones recognizes the difference between earnings and operating cash flow as accruals. This approach shows that the operating cash flow information is more objective criteria for firm real economic performance measures and hasn't been manipulated. Jones (1991) assumed that nondiscretionary accruals are fixed during the time period. The model tries to separate discretionary accruals and non-discretionary accruals and control the effect of entity economical situation on non-discretionary accruals.

The current study is to examine the limiting factors of earnings management for companies' listed Tehran stock exchange.Among different type of management, income, smoothing and income payments management is more important. The main issue is that managers use flexibility made from accounting standards in order to manipulate earnings. When firms have high performance income and produce more, the personal commitment will be increased (decreased). There are deferent kinds of intensives for these actions consist of tend to understand the impact of risk factors for sale, maintain dividend policy and Achievement of employee objectives in the context of the theory of agency and compensation (Greenawalt and Stinkey, 1988; Healy and Wahlen, 1999).

\subsection{Limiting factors of earnings management}

Control mechanisms might limit earnings management. Beasley (1996) and Bradbery (2006) showed that there is an inverse relationship between board size and discretionary accruals. Earnings management is so important because of its protective features for investment. Laporta et al (2000) in their study indicate that there is a positive relationship between shareholder protection and dividend.

Zarvin \& Cohn (2010) investigated SEOs earnings management behavior focused on accrual and real action manipulation during 1987-2006. They used cross-level Jones model (1991) in order to measure earnings management based accruals (Defond and Jiambalvo, 1994; Soubramaniam, 
1996). And they used operating cash flows, discretionary spending and the cost of product in order to measure real earnings management (Roychowdhury, 2006). They suggest three chapters in literature by the combination of SEO earnings management and real earnings management. First, they predicated firms that use real earnings management as well as accrual earnings management. Second, they showed the variation of firms intensive to compare real earnings management with SEO accrual earnings management. They found that firm election is changed as a function of firm capability to use of accrual management and its costs predictably. That was the first model about that how firms can make balance between real earnings management and accruals earnings management.

The third and most important one is that they investigated the effects of earnings management strategies on post-SEO performance efficiency. They found that the reduction of Post- SEO performance efficiency for real activities is more intense than accruals management. That shows reduction of Post- SEO performance efficiency is motivated by reverse accruals (Rengan, 1998; Theo et al 1998). And also reflect real outcomes of operating decisions about SEO earnings management. All-told, their finding shows the reliability of SEO earnings management. In the following in order to better understanding of the relationship between real earnings management and accrual earnings management, this issue will be discussed extensively.

\section{Research Hypotheses}

Hypothesis 1: There is a significant relationship between board size and earnings management for companies' listed Tehran stock exchange.

Hypothesis 2: There is a significant relationship between dividend and earnings management for companies' listed Tehran stock exchange.

\section{Research variable}

\subsection{Dependent variable:}

Earnings management: in the current study Jones adjusted model by Dechow et al (1998) is used in order to measure earnings management.

$$
\frac{T A_{i t}}{A_{i t-1}}=\alpha_{1}\left[\frac{1}{A_{i t-1}}\right]+\alpha_{2}\left[\frac{\left(\Delta R E V_{i t}-\Delta A R_{i t}\right)}{A_{i t-1}}\right]+\alpha_{3}\left[\frac{P P E_{i t}}{A_{i t-1}}\right]+\varepsilon_{i t}
$$

\section{$T A_{i t}:$ Firm total accrual}

$A_{i t-1}$ Firm total assets

$\triangle R E V_{i t}-\triangle A R_{i t}$ Changing in cash revenue 


\section{$P P E_{i t}$ Property}

\subsection{Independent variable}

Board size: the log of the number of board member is used in order to measure this variable.

Dividend policy

\subsection{Control variables:}

Book to market ratio is considered as control variable.

\section{Research domain}

Subject domain:The investigation of limiting factors of earnings management for companies' listed Tehran stock exchange.

Locative domain: companies' listed Tehran stock exchange.

Time domain: the years during 2009-2013

\section{Statistical population and sample:}

Statistical population and data has been selected considering following restrictions and systematic elimination method:

1) Be acceptable in stock market since 2009

2) The end of financial year is $19^{\text {th }}$ March.

3) The companies being in manufacture industry and In order to ensure comparability of their activity do not invest and finance in companies such insurance and banks.

4) The financial year has not been changed during financial period.

5) The firms which have available information necessarily during the study period.

6) Be acceptable in stock market until 2013

\section{RESEARCH METHOD}

The current paper is a kind of descriptive - correlative study. That is a descriptive study because it describes and recognizes conditions or phenomenon. And the study is correlative because it investigates the correlation between variables and seeks to prove the relationships based historical data. So, the current study can be categorized as a post event study cause of investigating cause and effect. In this paper there is a significant relationship between variables and the variables are not manipulated. 
8. Model:

Dis_Accurals $_{\mathrm{it}}=\alpha_{0}+\beta_{1} B O A R D_{\mathrm{it}}+\beta_{2} B M V_{\mathrm{it}}+\varepsilon_{\mathrm{it}}$

Dis_Accurals $_{\mathrm{it}}=\alpha_{0}+\beta_{1} D I V_{\mathrm{it}}+\beta_{2} B M V_{\mathrm{it}}+\varepsilon_{\mathrm{it}}$

\section{RESULTS}

9.1 Chow test or the test of structural changes in hypothesis:

In order to test hypothesis, first of all time fixed effect models are estimated and then structural changes test is used for investigating significance difference.

\begin{tabular}{|l|l|l|l|l|}
\hline Hypothesis & $\begin{array}{l}\text { Cross sectional } \\
\text { cut }\end{array}$ & statistics & Freedom degree & significance \\
\hline \multirow{2}{*}{1} & F & $\mathbf{0 . 3 5 2 6 9 6}$ & $\mathbf{( 1 2 0 , 1 7 6 )}$ & $\mathbf{0 . 5 8 3 4}$ \\
\cline { 2 - 5 } & Chi-Square & $\mathbf{4 9 . 3 4 9 4 9 6}$ & Chi-Square & $\mathbf{0 . 4 7 9 2}$ \\
\hline \multirow{2}{*}{2} & F & $\mathbf{0 . 6 3 2 6 1 2}$ & F & $\mathbf{0 . 9 9 8 0}$ \\
\cline { 2 - 4 } & Chi-Square & $\mathbf{8 1 . 4 7 6 4 4 6}$ & Chi-Square & $\mathbf{0 . 9 8 4 0}$ \\
\hline
\end{tabular}

10. Durability test for research variable

\begin{tabular}{|l|l|l|l|l|}
\hline & Lovin, Lin \& Cho & $\begin{array}{l}\text { Eim, pesran \& } \\
\text { Shin }\end{array}$ & $\begin{array}{l}\text { Generalized } \\
\text { Fisher-Dickyfuler }\end{array}$ & $\begin{array}{l}\text { Fisher- } \\
\text { philips,pron }\end{array}$ \\
\hline \multirow{2}{*}{ Size } & -27.0402 & -3.21542 & $\mathbf{2 5 2 . 9 2 9}$ & $\mathbf{4 5 4 . 5 2 0}$ \\
\hline \multirow{2}{*}{ Board } & $\mathbf{0 . 0 0 0 0}$ & $\mathbf{0 . 0 0 0 0}$ & $\mathbf{0 . 0 0 0 0}$ & $\mathbf{0 . 0 0 0 0}$ \\
\hline \multirow{2}{*}{ DIV } & $\mathbf{- 8 . 1 4 7 1 0}$ & $\mathbf{4 . 5 7 8 4 6}$ & $\mathbf{1 6 1 . 7 0 3}$ & $\mathbf{2 5 . 4 1 1 6}$ \\
\cline { 2 - 5 } & $\mathbf{0 . 0 0 0 0}$ & $\mathbf{0 . 0 5 6 5}$ & $\mathbf{0 . 0 9 5 6}$ & $\mathbf{0 . 0 0 0 0}$ \\
\hline BMV & $\mathbf{- 5 3 . 5 1 0 0}$ & $-\mathbf{1 7 . 1 9 9 0}$ & $\mathbf{3 8 2 . 4 8 6}$ & $\mathbf{5 1 2 . 6 0 0}$ \\
\cline { 2 - 5 } & $\mathbf{0 . 0 0 0 0}$ & $\mathbf{0 . 0 1 9 2}$ & $\mathbf{0 . 0 0 0 1}$ & $\mathbf{0 . 0 0 0 0}$ \\
\hline & $\mathbf{3 3 4 . 9 0 8}$ & $\mathbf{- 3 1 . 0 7 2 9}$ & $\mathbf{- 5 . 8 4 6 4 6}$ & $\mathbf{3 4 0 . 9 2 5}$ \\
\cline { 2 - 5 } & $\mathbf{0 . 0 0 0 0}$ & $\mathbf{0 . 0 0 0 0}$ & $\mathbf{0 . 0 0 0 0}$ & $\mathbf{0 . 0 0 0 0}$ \\
\hline
\end{tabular}

11. heteroscadasticity pre-tests method

\begin{tabular}{|c|c|c|c|c|}
\hline \multicolumn{5}{|l|}{ Hypothesis 1} \\
\hline & \multicolumn{2}{|l|}{ statistics } & \multicolumn{2}{|c|}{ Statistics probability } \\
\hline \multirow{3}{*}{$\begin{array}{l}\text { Brosh-Pagan } \\
\text { gadfery }\end{array}$} & F-statistic & $\mathbf{3 . 3 2 5 2 0 1}$ & Prob. F(2,164) & 0.0018 \\
\hline & Obs*R-squared & 7.008712 & $\begin{array}{l}\text { Prob. } \\
\text { Square(2) }\end{array}$ & 0.0018 \\
\hline & $\begin{array}{ll}\text { Scaled } & \text { explained } \\
\text { SS } & \\
\end{array}$ & 3.765410 & $\begin{array}{ll}\text { Prob. } & \text { Chi- } \\
\text { Square(2) }\end{array}$ & 0.0886 \\
\hline
\end{tabular}




\begin{tabular}{|c|c|c|c|c|}
\hline \multicolumn{5}{|l|}{ Hypothesis 2} \\
\hline & \multicolumn{2}{|l|}{ statistics } & \multicolumn{2}{|c|}{ Statistics probability } \\
\hline \multirow{3}{*}{$\begin{array}{l}\text { Brosh-Pagan } \\
\text { gadfery }\end{array}$} & F-statistic & 0.339289 & Prob. F(2,164) & 0.1234 \\
\hline & Obs*R-squared & 0.698320 & $\begin{array}{ll}\text { Prob. } & \text { Chi- } \\
\text { Square(2) }\end{array}$ & 0.0239 \\
\hline & $\begin{array}{ll}\text { Scaled } & \text { explained } \\
\text { SS } & \\
\end{array}$ & 0.586195 & $\begin{array}{ll}\text { Prob. } & \text { Chi- } \\
\text { Square(2) }\end{array}$ & 0.0972 \\
\hline
\end{tabular}

- H1: There is a significant relationship between board size and earnings management for companies' listed Tehran stock exchange.

Dis_Accruals it $_{-}=\alpha_{0}+\beta_{1} B O A R D_{\mathrm{it}}+\beta_{2} B M V_{\mathrm{it}}+\varepsilon_{\mathrm{it}}$

$H_{0}:$ There is not any significant relationship between Dis-accruals and Board

$H_{1}$ : There is a significant relationship between Dis-accruals and Board

12. The result of Hypothesis 1 test

\begin{tabular}{|c|c|c|c|c|}
\hline variables & coefficient & \begin{tabular}{|l|} 
Standard \\
deviation
\end{tabular} & t statistics & significance \\
\hline fixed & 1.121297 & 0.321746 & 3.485043 & 0.0005 \\
\hline Board size & -1.592533 & 0.456951 & -3.485126 & 0.0005 \\
\hline $\begin{array}{l}\text { Book to market } \\
\text { ratio }\end{array}$ & 0.009162 & 0.005022 & 1.824142 & 0.1287 \\
\hline $\begin{array}{l}\text { Determination } \\
\text { Coefficient }\end{array}$ & 0.257654 & $\begin{array}{l}\text { The mean of } \\
\text { dependent } \\
\text { variable }\end{array}$ & -0.021098 & \\
\hline $\begin{array}{l}\text { Adjusted } \\
\text { Determination } \\
\text { Coefficient }\end{array}$ & 0.138634 & $\begin{array}{l}\text { Standard } \\
\text { deviation } \\
\text { dependent } \\
\text { variable }\end{array}$ & 1.113033 & \\
\hline $\begin{array}{l}\text { Regression } \\
\text { error }\end{array}$ & 1.238409 & $\begin{array}{l}\text { The remaining } \\
\text { amount of } \\
\text { square }\end{array}$ & 657.2333 & \\
\hline F statitics & 1.689886 & \begin{tabular}{|l|} 
Dourbin \\
Watson \\
\end{tabular} & 2.135909 & \\
\hline $\begin{array}{ll}\text { F } & \text { statistics } \\
\text { porob } & \\
\end{array}$ & 0.000036 & & & \\
\hline
\end{tabular}

According to table as the amount statistic Dourbin - Watson test is 2.13 and model index in alpha error level is more than $5 \%$, so the assumption of the lack of correlation between errors is 
accepted and the Regression model can be used. The amount of adjusted determination coefficient is $13 \%$ which indicate that $13 \%$ of changes in total research dependent variable depend on independent and control variables in this model. According to significance of $t$ statistics there is significant relationship between board size and earnings management for companies' listed Tehran stock exchange.

- H2: There is a significant relationship between dividend and earnings management for companies' listed Tehran stock exchange.

Dis_Accurals $_{\mathrm{it}}=\alpha_{0}+\beta_{1} D I V_{\mathrm{it}}+\beta_{2} B M V_{\mathrm{it}}+\varepsilon_{\mathrm{it}}$

$H_{0}:$ There is not any significant relationship between Dis-accruals and DIV

$H_{1}$ : There is a significant relationship between Dis-accruals and DIV

13. The result of Hypothesis 2 test

\begin{tabular}{|c|c|c|c|c|}
\hline Variables & coefficient & $\begin{array}{l}\text { Standard } \\
\text { deviation }\end{array}$ & t statistics & significance \\
\hline Fixed & 0.19057 & 0.157890 & 1.501901 & 0.1412 \\
\hline Board size & -0.126133 & \begin{tabular}{|l|}
0.101239 \\
\end{tabular} & -1.245899 & 0.2314 \\
\hline $\begin{array}{l}\text { Book to market } \\
\text { ratio }\end{array}$ & $-\mathbf{0 . 1 0 8 1 8 0}$ & 0.163548 & -0.661455 & 0.5086 \\
\hline $\begin{array}{l}\text { Determination } \\
\text { Coefficient }\end{array}$ & 0.132912 & $\begin{array}{l}\text { The mean of } \\
\text { dependent } \\
\text { variable }\end{array}$ & 0.036989 & \\
\hline $\begin{array}{l}\text { Adjusted } \\
\text { Determination } \\
\text { Coefficient }\end{array}$ & 0.081720 & $\begin{array}{l}\text { Standard } \\
\text { deviation of } \\
\text { dependent } \\
\text { variable }\end{array}$ & 0.996972 & \\
\hline $\begin{array}{l}\text { Regression } \\
\text { error }\end{array}$ & 1.035465 & $\begin{array}{l}\text { The remaining } \\
\text { amount of } \\
\text { square }\end{array}$ & 3.082610 & \\
\hline F statistics & 1.984390 & $\begin{array}{l}\text { Dourbin } \\
\text { Watson } \\
\end{array}$ & 1.201781 & \\
\hline $\begin{array}{ll}\text { F } & \text { statistics } \\
\text { porob } & \\
\end{array}$ & 0.000046 & & & \\
\hline
\end{tabular}


According to table as the amount statistic Dourbin - Watson test is 1.2 and model index in alpha error level is more than $5 \%$, so the assumption of the lack of correlation between errors is accepted and the Regression model can be used. The amount of adjusted determination coefficient is $8 \%$ which indicate that $8 \%$ of changes in total research dependent variable depend on independent and control variables in this model. According to significance of $\mathrm{t}$ statistics there isn't any significant relationship between dividend and earnings management for companies' listed Tehran stock exchange.

\section{Study limitations:}

- For measuring earnings management by using accruals, some of the accruals because registration is not included in the calculation.

- In calculating fixed asset ratio, some of the items reflected in the balance sheet have not been properly recorded by companies or reflected in current assets. The diagnosis of this issue has not been possible for authors.

\section{References}

1. Aghayi, M, and Chalaki, P. The investigation of the relationship between corporate governance and earnings management for companies' listed Tehran stock exchange. Accounting review, 2009, 1(4): 54-77.

2. Ahmadpour et al. The effect of outside directors and institutional investors on earnings management behavior. Accounting and audit review, 2009,3.

3. Ath M, Kazsnik R and McNichols M, "Analyst Coverage and Intangible Assets", Journal of Accounting Research, 2001, 39(1): 1-34.

4. Beasley M S, "An Empirical Analysis of the Relation between the Board of Director Composition and Financial Statement Fraud”, the Accounting Review, 1996, 71(4): 443465.

5. Becker C, Defond M, Jiambalvo J and Subramanyam K R, "The Effect of Audit Quality on Earnings Management”, Contemporary Accounting Research, 1998, 15(1): 1-24.

6. Beneish M, "The Detection of Earnings Manipulation”, Financial Analysts Journal, 1999, 55(5): 24-36. 
7. Bergstresser D and Philippon T, "CEO Incentives and Earnings Management", Journal of Financial Economics, 2006, 80(3): 511-529.

8. Cadbury Report (1992), Report of the Committee on the Financial Aspects of Corporate Governance, Gee \& Co., London.

9. Cheng Q and Warfield T, "Equity Incentives and Earnings Management", Accounting Review, 2005, 80(2): 441-477.

10. Cormier D, Landry $\mathrm{S}$ and Magnan $\mathrm{M}$, "Gestion du résultat ou optimisation fiscale? Évaluation des octrois d'options d'achat d'actions selon le contexte de gouvernance actionnariale", Canadian Journal of Administrative Sciences, 2006, 23(2) : 153-168.

11. DeAngelo H, DeAngelo L and Skinner D, "Reversal of Fortune Dividend Signaling and the Disappearance of Sustained Earnings Growth", Journal of Financial Economics, 1996, 40(1): 341-371.

12. DeAngelo L, "Accounting Numbers as Market Valuation Substitutes: A Study of Management Buyouts of Public Stockholders", The Accounting Review, 1986, 61(3): 400420.

13. Dechow P-M “Accounting Earnings and Cash Flows as Measures of Firm Performance: The Role of Accounting Accruals", Journal of Accounting and Economics, 1994, 18(1): 342.

14. Dechow P-M and Sloan R, "Executive Incentives and the Horizon Problem: An Empirical Investigation", Journal of Accounting and Economics, 1991, 14(1): 51-89.

15. Defond M and Jiambalvo J , "Incidences and Circumstances of Accounting Errors", The Accounting Review, 1991, 66(3): 643-655.

16. Degeorge F, Patel J and Zeckhauser R, "Earnings Management to Exceed Thresholds", Journal of Business, 1999, 72(1): 1-33.

17. Ebrahimi Kordlor, A, and Seyedi, S. The role of auditors in discretionary accruals reduction, accounting and audit review. 2008, 4: 78

18. Erickson M, Hanon M and Maydew E L, "How Much Will Firms Pay for Earnings that Do Not Exist? Evidence of Taxes Paid on Allegedly Fraudulent Earnings", The Accounting Review, 2004, 79(2): 387-408.

19. Esmaeili, M. The main considerations in the process of capital budgeting. Bours magazine. 2006, 32: 58 
20. Etemadi, H, and Farajzade dehkordi, H. The effect of earnings management and capital structure on earnings conservatism. accounting and audit review. 2012,17.

21. Fama E F, "Agency Problems and the Theory of the Firm", Journal of Political Economy, 1980, 88(2): 288-307.

22. Fama E F and Jensen M C, "Separation of Ownership and Control", Journal of Law and Economics, 1983, 26(2): 301-325.

23. Fernandez C and Garcia R A (), "The Effects of Ownership Structure and Board Composition on the Audit Committee Meeting Frequency: Spanish Evidence”, Corporate Governance: An International Review, 2007, 15(5), : 909-922.

24. Gaver J, Gaver K and Austin J, "Additional Evidence on Bonus Plans and Income Management”, Journal of Accounting and Economics, 1995, 19(1): 3-28.

25. Graham J, Harvey $\mathrm{C}$ and Rajgopal S, "The Economic Implications of Corporate Financial Reporting", Journal of Accounting and Economics, 2005, 40(1-3): 3-73.

26. Greenawalt, M., J. Sinkey, Jr., (1988). Bank loan loss provisions and the income smoothing hypothesis: An empirical analysis, 1976-1984, Journal of Financial Services Research 1, 301-318.

27. Guidry F, Leone A J and Rock S, "Earnings-Based Bonus Plans and Earnings Management by Business-Unit Managers", Journal of Accounting \& Economics, 1999, 26,(1-3): 113142.

28. Han J C Y and Wang S, "Political Costs and Earnings Management of Oil Companies During the 1990 Persian Gulf Crisis", The Accounting Review, 1998, 73(3) : 103-117.

29. Healy, P. M. \& Wahlen, J. M. "A Review of the Earning Management Literature and Its Implications for Standard Setting” Accounting Horizons, 1999, 13: 365-383.

30. Hirshleifer D, "Managerial Reputation and Corporate Investment Decisions", Financial Management, 1993, 22,(2): 145-160.

31. Jensen M-C, "Agency Costs of the Free Cash Flow, Corporate Finance and Takeovers", American Economic Review, 1986, 76(2): 323-329.

32. Jensen M and Meckling W, "Theory of the Firm: Managerial Behavior, Agency Costs and Ownership Structure", Journal of Financial Economics, 1976, 3(4): 305-360.

33. Jones J, "Earnings Management during Import Relief Investigations", Journal of Accounting Research, 1991, 29(2): 193-228. 
34. Khodadadi, V, and Kargarpour, K. The relationship between operating cash flow and cash ratio with stock return in companies' listed Tehran stock exchange. Financial accounting review, 2009, 1(1): 60-75

35. Klassen K, "The Impact of Inside Ownership Concentration on the Trade-Off Between Financial and Tax Reporting", The Accounting Review, 1997 72(3): 455-474.

36. Klein A, "Audit Committee, Board of Director Characteristics, and Earnings Management”, Journal of Accounting and Economics, 2002,33(3): 375-400.

37. Kothari S P, Leone A J and Wasley C E, "Performance Matched Discretionary Accruals", Journal of Accounting and Economics, 2005, 39(1): 23-49.

38. La Porta R, Lopez-de-Silanes F, Shleifer A and Vishny R, "Investor Protection and Corporate Governance”, Journal of Financial Economics, 2000, 58(1): 3-27.

39. McNichols M F, "Discussion of the Quality of Accruals and Earnings: The Role of Accrual Estimation Errors", The Accounting Review, 2002, 77 (Supplement): 61-69.

40. Omri A, "Systèmes de gouvernance et performance des entreprises tunisiennes", Revue Française de Gestion, $2001: 85-100$.

41. Peasnell K, Pope P and Young S, "Detecting Earnings Management Using CrossSectional Abnormal Accruals Models", Accounting and Business Research, 2000, 30(4): 313-326

42. Peasnell K, Pope P and Young S, "Managerial Equity Ownership and the Demand for Outside Directors”, European Financial Management, 2003, 9(2): 231-250.

43. Peasnell K, Pope P and Young S, "Board Monitoring and Earnings Management: Do Outside Directors Influence Abnormal Accruals?", Journal of Business Finance and Accounting, 2005, 32(7) : 1311-1346.

44. Raman K and Shahrur H, "Relationship-Specific Investments and Earnings Management: Evidence on Corporate Suppliers and Customers", The Accounting Review, 2008, 83(7): 1041-1081.

45. Roychowdhury S, "Earnings Management Through Real Activities Manipulation”, Journal of Accounting and Economics, 2006, 42(3): 335-370.

46. Sanchez-Ballesta J and Garcia-Meca B, "Ownership Structure, Discretionary Accruals and the Informativeness of Earnings”, Corporate Governance, 2007, 15(4): 677-691. 
47. Sepasi, S, Noravesh, I, and Nikbakht, M. Earnings management in companies' listed Tehran stock exchenge. Human social science2005, 43

48. Shokry, Z, Moghadaspour, H, and Ghasemi, M. The relationship between capital predictability, earning per share and P/E with stock return in companies' listed Tehran stock exchange.Development and capital journal, 2009, 2(3): 151-173

49. Stubben S R, "Discretionary Revenues as a Measure of Earnings Management", The Accounting Review, 2010, 85(2): 695-717.

50. Tariverdi, Y, and Samarikhalj, E. Earnings management by using long-run assets sale timeliness. Accounting and audit review, 2012, 15

51. Tehrani, R, and Vafni Asl, M. The relationship between operating cash flow and accrual earning with stock return in companies' listed Tehran stock exchange, 2007, 9(24): 21-32

52. Teoh S-H, Welch I and Wong T-J, "Earnings Management and the Long Run Market Performance of Initial Public Offerings", The Journal of Finance, 1998, 53(6): 1935-1974.

53. Xie B, Davidson III W N and Peter J D, "Earnings Management and Corporate Governance: The Role of the Board and the Audit Committee", Journal of Corporate Finance, 2003, 9(3): 295-316.

54. Yermack D, "Good Timing: CEO Stock Option Awards and Company News Announcements", Journal of Finance, 1997, 52(2): 449-476.

55. Zariffard, A. The problem of ambiguity and vagueness in Accounting. Accounting and audit review, 1999, 15(51) 37

\section{How to cite this article:}

Tangestani E, Asgari V, Jahed I. The investigation of limiting factors of earnings management for companies' listed tehran stock exchange. J. Fundam. Appl. Sci., 2016, 8(2S), 1559-1571. 